\title{
Linkage Analysis in a Dutch Population Isolate Shows No Major Gene for Left-Handedness or Atypical Language Lateralization
}

\author{
@Detten Somers, ${ }^{1}$ Roel A. Ophoff,,${ }^{1,2,3}$ Maartje F. Aukes, ${ }^{1}$ Rita M. Cantor, ${ }^{2}$ Marco P. Boks, ${ }^{1}$ Meenakshi Dauwan, ${ }^{1}$ \\ Kees L. de Visser, ${ }^{4}$ René S. Kahn, ${ }^{1}$ and Iris E. Sommer ${ }^{1}$ \\ ${ }^{1}$ Brain Center Rudolf Magnus, Department of Psychiatry, University Medical Center Utrecht, 3508 GA Utrecht, The Netherlands, ${ }^{2}$ Department of Human \\ Genetics David Geffen School of Medicine at University of California, Los Angeles, Gonda (Goldschmied) Neuroscience and Genetics Research Center, Los \\ Angeles, California 90095-7088, ${ }^{3}$ Center for Neurobehavioral Genetics, Semel Institute for Neuroscience and Human Behavior, Los Angeles, California \\ 90095-1761, and ${ }^{4}$ Department of General Practice, University Medical Center Groningen, University of Groningen, 9700 AD Groningen, The Netherlands
}

Cerebral dominance of language function and hand preference are suggested to be heritable traits with possible shared genetic background. However, joined genetic studies of these traits have never been conducted. We performed a genetic linkage study in 37 multigenerational human pedigrees of both sexes (consisting of 355 subjects) enriched with left-handedness in which we also measured language lateralization. Hand preference was measured with the Edinburgh Handedness Inventory, and language lateralization was measured with functional transcranial Doppler during language production. The estimated heritability of left-handedness and language lateralization in these pedigrees is 0.24 and 0.31 , respectively. A parametric major gene model was tested for left-handedness. Nonparametric analyses were performed for left-handedness, atypical lateralization, and degree of language lateralization. We did not observe genome-wide evidence for linkage in the parametric or nonparametric analyses for any of the phenotypes tested. However, multiple regions showed suggestive evidence of linkage. The parametric model showed suggestive linkage for left-handedness in the 22q13 region [heterogeneity logarithm of odds $(\mathrm{HLOD})=2.18$ ]. Nonparametric multipoint analysis of left-handedness showed suggestive linkage in the same region [logarithm of odds $(\mathrm{LOD})=2.80$ ]. Atypical language lateralization showed suggestive linkage in the $7 \mathrm{q} 34$ region $\left(\mathrm{LOD}_{\text {Max }}=2.35\right)$. For strength of language lateralization, we observed suggestive linkage in the $6 \mathrm{p} 22\left(\mathrm{LOD}_{\mathrm{Max}}=2.54\right), 7 \mathrm{q} 32\left(\mathrm{LOD}_{\mathrm{Max}}=\right.$ $1.93)$, and $9 \mathrm{q} 33\left(\mathrm{LOD}_{\mathrm{Max}}=2.10\right)$ regions. We did not observe any overlap of suggestive genetic signal between handedness and the extent of language lateralization. The absence of significant linkage argues against the presence of a major gene coding for both traits; rather, our results are suggestive of these traits being two independent polygenic complex traits.

Key words: asymmetry; genetics; hand-preference; language lateralization; left-handedness; linkage analysis

\section{Introduction}

Handedness is the most pronounced lateralized function in humans. The great majority of people have right-hand preference, but $10 \%$ of all populations is left-handed (McManus 2009).

\footnotetext{
Received Aug. 1, 2014; revised April 4, 2015; accepted April 10, 2015

Author contributions: M.S., R.A.O., M.F.A., M.P.B., K.C.L.d.V., R.S.K., and I.E.S. designed research; M.S. and M.D. performed research; M.S., R.M.C., and M.P.B. analyzed data; M.S., M.F.A., and I.E.S. wrote the paper.

This study was supported by MD Clinical Research Trainee Grant ZonMw 40-00703-98-8571 and a National Alliance for Research on Schizophrenia and Depression Independent investigator grant (I.S.). Statistical analyses were performed on the Genetic Cluster Computer (www.geneticcluster.org), which is financially supported by Netherlands Scientific Organization Grant 480-05-003. Some of the results were obtained by using the software package S.A.G.E., which was supported by U.S. Public Health Service Resource Grant RR03655 from the National Center for Research Resources. We thank E. Strengman and R. van 't Slot for their assistance in the genotyping procedures, Dr K. R. van Eijk for her advice on formatting raw data, and A. Bos-Korf, M. Essed, W. Fleer, C. van de Moosdijk, F. M. van Nieuwenhuijze, A. Oost-Korf, and E. Schrijver for their role in the data collection.

The authors declare no competing financial interests.

Correspondence should be addressed to Metten Somers, Brain Center Rudolf Magnus, Department of Psychiatry, University Medical Center Utrecht, A01.4.68, P.0. Box 85500, 3508 GA Utrecht, The Netherlands. E-mail: M.Somers@umcutrecht.nl.

DOI:10.1523/JNEUROSCI.3287-14.2015

Copyright $\odot 2015$ the authors $\quad 0270-6474 / 15 / 358730-07 \$ 15.00 / 0$
}

There is considerable evidence that hand preference is determined partly by genetic factors. Adoption studies show that handedness of a child is determined by handedness of the biological parents and not by hand preference of the adoption parents (Carter-Saltzman, 1980). Twin studies show a modest heritability of left-handedness, estimated at 24\% (Medland et al., 2009). Several genetic studies have shown linkage or association with a variety of genetic regions (Van Agtmael et al., 2003; Warren et al., 2006; Francks et al., 2007; Scerri et al., 2011).

An important reason for the interest in the genetics of lefthandedness is the relation between hand preference and language lateralization: although $95 \%$ of right-handed subjects have lefthemispheric dominance for language function, some left-handed subjects show a different pattern. Left-handed subjects show lefthemispheric dominance in $75 \%$ of cases, but the remaining $25 \%$ has right-hemispheric or bilateral lateralization ("atypical lateralization"). Given the larger chance for atypical lateralization in left-handed subjects, it is often hypothesized that left-handedness and atypical lateralization are determined by the same genes (McManus, 1985; Annett, 1999; Smalley et al., 2005). Familial aggrega- 
tion data show that language lateralization is also under genetic influence (Anneken et al., 2004). Several candidate gene studies have shown an association with genetic variants, e.g., in NMDA receptor, FOXP2 (Forkhead box protein P2), and cholecystokinin-A receptor genes (Ocklenburg et al., 2011, 2013; Pinel et al., 2012; Arning et al., 2013), but so far, no genome-wide studies of language lateralization have been performed.

Two major gene models have shaped theories regarding the genetic origins of lateralization: the "right-shift factor" (Annett and Turner, 1974; Annett, 1998) and the McManus model (McManus, 1985). In both models, the dominant allele favors development of right-handedness and left cerebral dominance for language. An increased loading on the minor allele increases the chance of developing left-handedness and right cerebral dominance. Homozygosity for the minor allele results in a $50 \%$ chance for either side in both traits (McManus, 1985). Although recent genome-wide association study (GWAS) findings argue against a major handedness gene (Armour et al., 2014), the above models have never been tested in a genetic family study. Furthermore, the genetics of hand preference and language lateralization have only been investigated separately. The hypothesis of a major gene underlying lateralization of handedness and language can be tested by genome-wide linkage analysis in families (Lander and Kruglyak, 1995).

In this study, we estimate the heritability of handedness and language lateralization and test the presence of a major gene through genome-wide linkage analysis in large pedigrees with multiple left-handed subjects in multiple generations. Pedigrees were collected in large families of a Dutch population isolate. We expect that linkage analysis in this population isolate results in increased power to identify genetic regions linked to language lateralization and hand preference. Language lateralization was measured with functional transcranial Doppler (fTCD), a mobile technique that allows to reliably measure lateralization in large samples (Deppe et al., 2004; Somers et al., 2011). Hand preference was measured with the Edinburgh Handedness Inventory (EHI).

\section{Materials and Methods}

Study population. We included 368 human subjects of both sexes from 37 families from a single town with $\sim 19,500$ inhabitants representing a population isolate in The Netherlands. Founders in our sample have a lower genetic heterogeneity than random Dutch population samples, as expressed by a lower decay of linkage disequilibrium with increasing genetic distance and increased identity by descent (IBD) sharing (M. Somers, L. Olde Loohuis, M. F. Aukes, B. Pasaniuc, C. L. de Visser, R. S. Kahn, I. E. Sommer, and R. A. Ophoff, unpublished observations). This is primarily attributable to the geographical isolation and a bottleneck event in the early 17th century. The town was an island for many centuries until its connection to the mainland 75 years ago. The demography of the town is still characterized by strong social and religious coherence: inhabitants tend not to move outside the village, and $\sim 90 \%$ of inhabitants are a member of a church. The birth rate is high (3.0 children per mother), and almost $65 \%$ of people marry directly from their parental home (Dutch Bureau for Statistics). As a result, most families are large and multigenerational. We enriched the sample for atypical lateralization by selecting only those pedigrees that had left-handed subjects in at least two generations, with at least two left-handed subjects per generation. As many subjects as possible from a selected family were enrolled. Participants had to be at least 14 years of age to be included. They were recruited through an advertisement in a local newspaper that was also distributed to all patients of general practitioners during registration for an appointment at the front desk. The advertisement included a screening list for a subject's hand preference, as well as familial hand preference. The study was approved by the Human Ethics Committee of the University Medical
Center, Utrecht, the Netherlands. After a complete description of the study to the subjects, written informed consent was obtained according to the Declaration of Helsinki.

Hand preference. Subjects were classified as right- or left-handed according to original writing hand, as determined with the EHI (Oldfield, 1971).

fTCD experiment: data acquisition. Language lateralization data were collected using fTCD. This is a portable device that can reliably measure a language lateralization index, expressing degree and direction of lateralization, with high reproducibility (Knecht et al., 1998; Deppe et al., 2004; Somers et al., 2011). It has low spatial resolution but allows determination of hemispheric activation. fTCD is especially useful to measure language lateralization in larger samples. A commercially available transcranial Doppler ultrasonography device (Multi-Dop T2; DWL) was used for continuous measurements of changes in cerebral blood-flow velocity $(\mathrm{CBFV})$. The left and right medial cerebral arteries (MCAs) were insonated at a depth of $40-55 \mathrm{~mm}$ with two $2 \mathrm{MHz}$ transducer probes attached to a screw-top headset, after placing the probes bilaterally at the temporal skull windows (Deppe et al., 2004). fTCD spectral envelope curves were recorded and stored at a rate of 28 sample points per second.

fTCD experiment: word-generation task. For the fTCD experiment, the procedures described by Deppe et al. (2004) were followed. After fixation of the headset and insonation of the MCAs, subjects were seated in front of a laptop computer. A word-production paradigm used in several fTCD studies and validated by the intracarotid amobarbital procedure was displayed on a laptop computer screen (Knecht et al., 1996). The test consisted of 20 trials. Each trial started with a $32.5 \mathrm{~s}$ baseline period during which the screen remained blank and subjects were instructed to think of nonverbal items (i.e., "a starry night"). At $t=32.5 \mathrm{~s}$, a cuing tone sounded, followed by a randomly picked letter at $t=37.5 \mathrm{~s}$ that was shown for $2.5 \mathrm{~s}$. Participants were instructed to silently generate as many words starting with the displayed letter as possible for $17.5 \mathrm{~s}$ until the next cuing tone $(t=55 \mathrm{~s})$ while watching a blank screen. They were instructed to overtly repeat the last silently generated words after the second tone to control performance. A third tone $(t=59 \mathrm{~s})$ indicated the end of a trial. Each trial contained a different letter, excluding Q, X, and Y, because these are infrequently used (i.e., in the Dutch language).

fTCD experiment: data analysis and calculation of lateralization indices. The AVERAGE software package was used for calculation of fTCD lateralization indices (LI-fTCD) by comparing changes in CBFV during covert word generation relative to resting state in both MCAs (Deppe et al., 1997). AVERAGE is designed to integrate fTCD data over the corresponding cardiac cycles. Data are consequently segmented into epochs time-locked to the cuing tone. These epochs can be averaged and analyzed to calculate lateralization indices. A measure of the mean interhemispheric difference in CBFV is provided by subtracting averaged changes in CBFV during activity relative to rest of the right and left MCAs. AVERAGE allows for calculation of the laterality index (LIfTCD) by integrating the $\triangle \mathrm{CBFV}$ over a $2 \mathrm{~s}$ period of maximal difference between the left and right MCA during silent word generation. For an elaborate description of this methodology, we refer to the study by Deppe et al. (1997). A positive LI-fTCD reflects predominant left-hemispheric language processing. A negative sign reflects predominant righthemispheric language processing. The magnitude of LI-fTCD reflects the degree of lateralization. To determine direction of language lateralization subjects were characterized as left (LI-fTCD $>1$ ) or atypical (bilateral or right-dominant, LI-fTCD $<1$; Knecht et al., 2000). Theoretically, the use of an integrating formula can result in lateralization indices ranging from $\infty$ to $-\infty$. However, in practice, indices range from 12 (extreme left dominance) to -12 (extreme left dominance). In addition, AVERAGE calculates the accuracy of LI-fTCD, expressed by its confidence interval.

Heritability analysis. The phenotypical association of left-handedness and atypical lateralization was calculated using the FCOR module of the Statistical Analysis for Genetic Epidemiology 6.2 (S.A.G.E.) software package (http://darwin.cwru.edu). We calculated broad heritability for hand preference and language lateralization as binary traits. Heritability analyses were performed using the ASSOC module in S.A.G.E. This module allows for heritability analyses of dichotomous traits. To calculate the heritability of left-handedness, the pedigrees were extended to $1033 \mathrm{sub}$ - 
jects with phenotypic data from nonparticipating or deceased family members that was supplied by participants. It may be assumed that the error in the reported hand preference of family members by participating subjects is low because of the conspicuousness of left-handedness. For the analysis of language lateralization as a dichotomous trait, data from 309 subjects could be used. Both analyses were adjusted for gender, by inserting gender as a covariate in the analysis.

Power analysis. We performed a power analysis using the analytical power calculation in POLY (Chen and Abecasis, 2006).

Linkage analysis. Blood was sampled in two $5 \mathrm{ml}$ EDTA tubes, and DNA was isolated and stored at $-80^{\circ} \mathrm{C}$. Samples were genotyped with the Illumina HumanLinkage-24 panel [5913 single nucleotide polymorphisms (SNPs)]. Genotyping was completed in 361 subjects (161 lefthanded subjects, 200 right-handed subjects). Quality control was performed using PLINK 1.06 (Purcell et al., 2007). SNPs with a genotyping rate below $95 \%(n=50)$, deviation from Hardy-Weinberg equilibrium ( set at $p<0.001, n=40$ ), and SNPs showing Mendelian errors $(n=$ $65)$ were removed. Furthermore, gender was checked with the PLINK sex-check module. One parent-child pair was removed for a gender ambiguity. We used the PLINK Genome module to match the IBD status of each subject with their position in the pedigree. A non-matching IBD status was present in one subject that was consequently removed. Pedigree structure was checked with the FAMTYPES (S. Purcell, Institute of Psychiatry, London, UK and Whitehead Institute, Massachusetts Institute of Technology, Cambridge, MA) module in PLINK and the PEDSTATS (Wigginton and Abecasis, 2005) module in MERLIN (Abecasis et al., 2002). No consanguineous loops were present within the pedigrees. Two families that were too large for linkage calculation in MERLIN were each split into two pedigrees. Three uninformative subjects from one family were removed. Hereafter, a total of 355 subjects with 5419 autosomal SNPs were available for linkage analysis using MERLIN. The dataset was checked for genotyping errors with the error-detection module in MERLIN. We performed SNP pruning at a threshold of $R^{2}<0.20$ using the pairwise-linkage disequilibrium (LD) pruning module in PLINK to control for possible inflation of the signal attributable to LD. This resulted in 4138 SNPs for analysis.

To investigate the presence of a major gene for left-handedness, the parametric rare-dominant single-gene model as described previously (McManus, 1985; Van Agtmael et al., 2003) was tested, by considering left-handedness as the affected status under a dominant model with reduced penetrance in which the disease ("C") allele has a frequency of 0.155 (Van Agtmael et al., 2001, 2003). Assuming a phenocopy rate of 5\% for subjects without the disease allele, DC heterozygote carriers of the disease alleles have a $25 \%$ chance, whereas homozygote carriers have a $50 \%$ chance of developing left-handedness. To test for model-free modes of inheritance, we performed nonparametric multivariate linkage with MERLIN (Abecasis et al., 2002), considering left-handedness as the affected status. In addition, we performed nonparametric multivariate linkage with MERLIN (Abecasis et al., 2002), considering atypical lateralization as the affected status. Also, nonparametric linkage analysis was performed with MERLIN (Abecasis et al., 2002) for strength of language lateralization, a quantitative measure. We applied the thresholds for suggestive and significant logarithm of odds (LOD) scores of 1.9 and 3.3, respectively, as suggested by Lander and Kruglyak (1995) to all analyses. To check for overlap in linked (subthreshold) regions across traits, we used an arbitrary cutoff of LOD $>1.5$, with a 1 LOD drop region.

\section{Results}

\section{Sample characteristics}

A total of 368 subjects ( 147 males and 221 females) from a total of 37 families participated in the study. The mean \pm SD age was $39 \pm$ 15.7. There were 202 right-handed subjects and 166 lefthanded subjects as classified by writing hand. The LI-fTCD could be measured successfully in 309 subjects (122 males and $187 \mathrm{fe}-$ males). In the remaining 58 subjects, the fTCD measurement failed or was inadequate, mainly because of low temporal bone translucency.
Table 1. Suggestive linkage regions showing trait, type of analysis, the top SNP, chromosomal region, and LOD score (HLOD for parametric analysis)

\begin{tabular}{lllll}
\hline Trait & Analysis & SNP & Chromosome & LOD \\
\hline Left-handedness & Major gene model & rs728592 & $22 q 13$ & 2.18 \\
Left-handedness & Model free & rs932497 & $22 q 13$ & 2.80 \\
Atypical lateralization & Model free & rs940864 & $7 \mathrm{q} 34$ & 2.35 \\
$\begin{array}{l}\text { Strength of language } \\
\quad \text { lateralization }\end{array}$ & Model free & rs2180419 & $6 \mathrm{p} 22$ & 2.46 \\
$\quad$ (QTL) & & & \\
$\begin{array}{l}\text { Strength of language } \\
\quad \text { lateralization }\end{array}$ & Model free & rs729332 & $7 \mathrm{q} 32$ & 1.93 \\
$\quad$ (QTL) & & & & \\
$\begin{array}{l}\text { Strength of language } \\
\quad \text { lateralization }\end{array}$ & Model free & rs 914652 & $9 \mathrm{q} 33$ & 2.19 \\
$\quad$ (QTL) & & & & \\
\hline
\end{tabular}

\section{Heritability analysis}

The extended sample contained a total of 37 families (of which one was split up), with an average size of $27.50 \pm 15.17$ (8-69 individuals). One pedigree consisted of two generations, 28 of three generations, and nine of four generations. The total number of left-handed subjects was 255 (24\%), and the total number of right-handed subjects was 778 . The pooled correlation of lefthandedness and atypical lateralization was $0.28(p=0.003)$. In females, the correlation was $r=0.30(p=0.0014)$, and the correlation in males was insignificant, with $r=0.19(p=0.07)$. The broad heritability of left-handedness in the extended sample $(n=$ $1033)$ was $0.24(p<10 \mathrm{E}-5)$. Adding gender as a covariate did not change the heritability. The heritability of atypical lateralization was $0.31(p=0.01)$. Adding gender as a covariate did not change the heritability. Adding left-handedness as a covariate lowered the heritability to $0.29(p=0.02)$.

\section{Power analysis}

For left-handedness, our sample showed $80 \%$ power to identify a locus that explains $28 \%$ of variance and $99 \%$ power to identify a locus that explains $46 \%$ of variance. For atypical lateralization, this was 32 and 53\%, respectively. For strength of language lateralization, this was 33 and $54 \%$ respectively. We used $p=0.05$ as our threshold.

\section{Linkage analysis: left-handedness, atypical lateralization, and strength of language lateralization}

Testing the major gene model for left-handedness (McManus, 1985; Van Agtmael et al., 2003) using the parametric analysis, we did not observe genome-wide evidence for linkage. Suggestive linkage peaks were detected at the chromosome $22 \mathrm{q} 13$ region $\left[\right.$ maximum heterogeneity LOD $\left(\mathrm{HLOD}_{\mathrm{Max}}\right)=2.18$, rs728592]. Model-free multipoint analysis showed overlapping suggestive linkage for left-handedness in the same chromosomal region $\left(\mathrm{LOD}_{\mathrm{Max}}=2.80, \mathrm{rs} 932497\right)$. Information content was well above 0.8 for all analyses. For an overview, see Table 1 and Figure 1, $A$ and $B$. Model-free multipoint analysis yielded no significant evidence of linkage. Suggestive linkage was observed for atypical language lateralization in the $7 \mathrm{q} 34$ region $\left(\mathrm{LOD}_{\text {Max }}=2.35\right.$, rs940864). For strength of language lateralization, we found suggestive linkage in the $6 \mathrm{p} 22\left(\mathrm{LOD}_{\mathrm{Max}}=2.46, \mathrm{rs} 2180419\right), 7 \mathrm{q} 32$ $\left(\mathrm{LOD}_{\text {Max }}=1.93\right.$, rs729332), and $9 \mathrm{q} 33\left(\mathrm{LOD}_{\mathrm{Max}}=2.19\right.$, rs914652) regions. Information content was well above 0.8 for all analyses. For an overview, see Table 1 and Figure $1 C-F$. We did not observe overlap in regions linked to handedness or language lateralization, using either a suggestive threshold of LOD $>1.9$ or a lower threshold of LOD > 1.5. 


\section{A \\ Left-handedness, parametric, chr22}

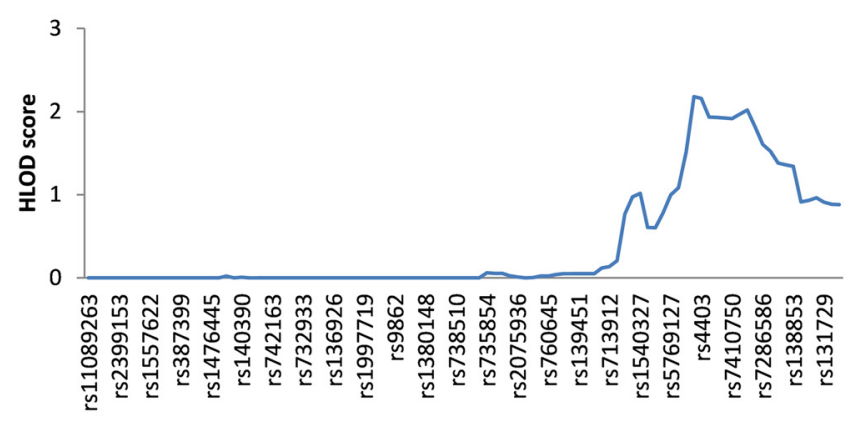

C Atypical lateralization, non-parametric, chr7

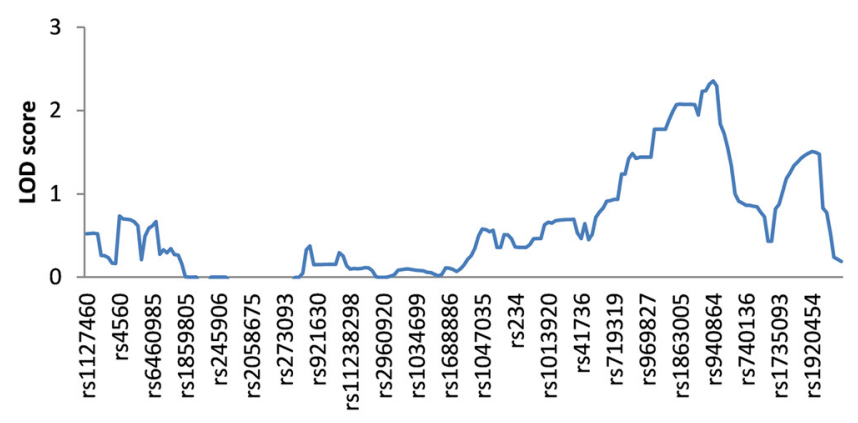

\section{E Language lateralization, QTL, non-parametric,} chr7

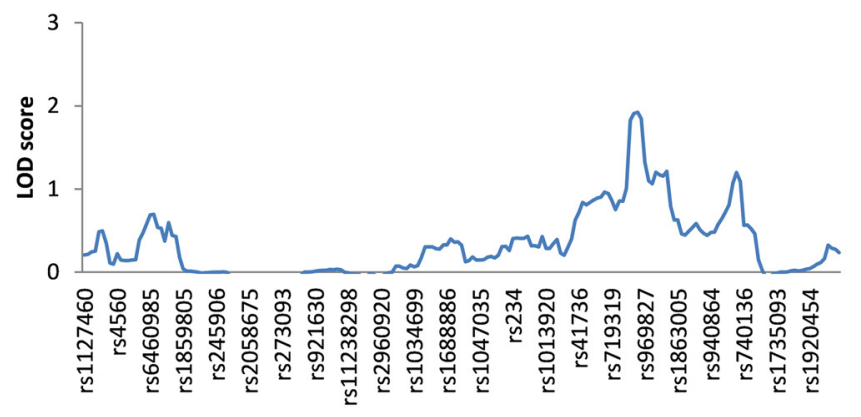

\section{B Left-handedness, non-parametric, chr22}

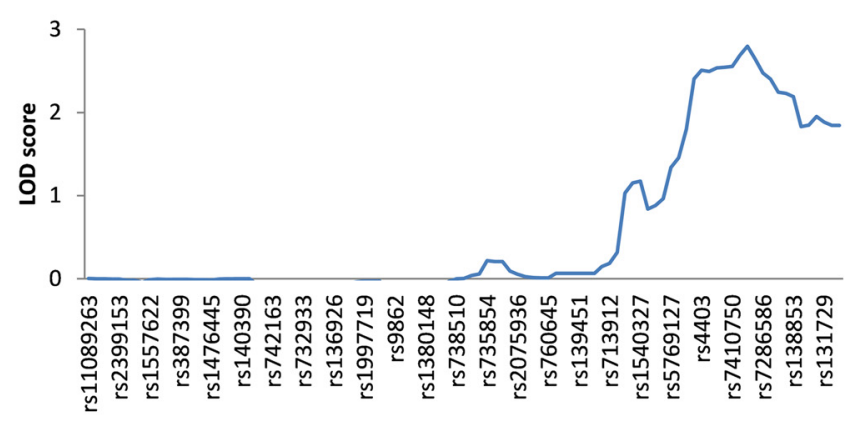

L Language lateralization, QTL, non-parametric,
chr6

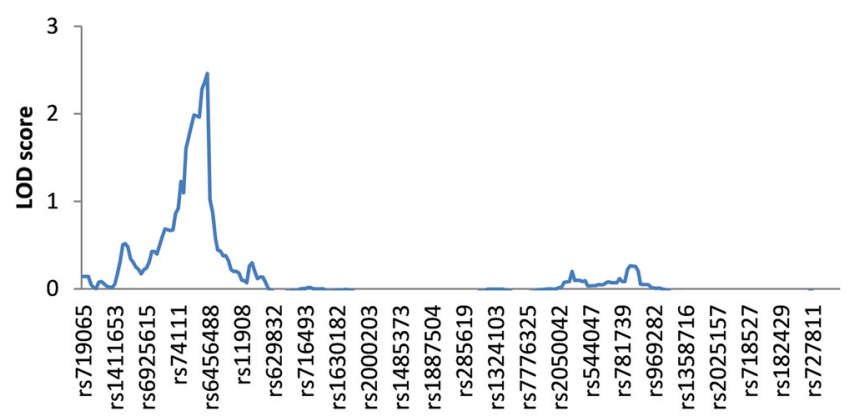

F Language lateralization, QTL, non-parametric, chr9

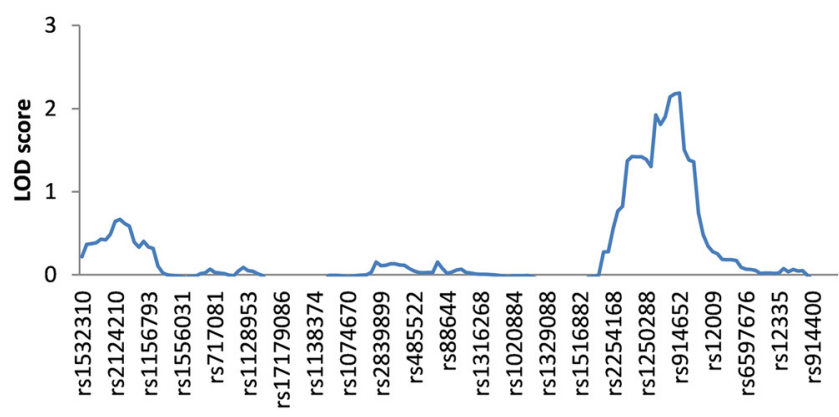

Figure 1. Linkage results in pruned datasets, showing RS numbers on the $x$-axis and LOD scores on they-axis (HLOD for parametric analysis) for left-handedness, parametric analysis, chromosome $22(\boldsymbol{A})$, left-handedness, nonparametric analysis, chromosome $22(\boldsymbol{B})$, atypical lateralization, nonparametric analysis, chromosome 7 (C), hand preference, quantitative trait loci (QTL), nonparametric analysis, chromosome 6 (D), language lateralization, QTL, nonparametric analysis, chromosome $7(\boldsymbol{E})$, and language lateralization, nonparametric analysis, chromosome $9(\boldsymbol{F})$.

\section{Discussion}

This is the first study to perform a genome-wide genetic linkage study of left-handedness and language lateralization together. The heritability of both traits was estimated, and the presence of a major gene was tested with genome-wide linkage analyses. Lefthandedness and language lateralization were measured in a total of 355 subjects from extended pedigrees with multiple lefthanded subjects from a Dutch population isolate. We did not observe any genetic linkage evidence in favor of a major gene for left-handedness or language lateralization. However, several chromosomal regions yielded peaks with suggestive evidence for linkage. We observed suggestive linkage at chromosome 22q13 for left-handedness, and we found suggestive linkage for atypical (right-hemispheric and bilateral) lateralization at chromosome $7 q 34$. For degree of language lateralization as measured with fTCD, a quantitative measure expressing the extent to which language func- tions are restricted to one hemisphere, suggestive linkage was found in regions $6 \mathrm{p} 22,7 \mathrm{q} 32$, and $9 q 33$. None of the regions were linked to both left-handedness and language lateralization. The absence of significant linkage indicates that there is no evidence for a major gene for left-handedness, atypical lateralization, or degree of language lateralization. It also shows that the genetic background of handedness and language lateralization is not shared.

Our results from the heritability analysis of left-handedness replicate previous findings, showing a heritability of $24 \%$. Results from the analysis of atypical language lateralization show a heritability of $31 \%$. This is the first heritability estimate for atypical lateralization. These findings indicate that both atypical language lateralization and left-handedness have a moderate heritability, even in a sample that is enriched for familial left-handedness. Thus, the heritability of left-handedness in the general population may even be lower. 
The absence of highly significant linkage in our sample argues against the presence of a major gene. If we take our suggestive results to represent true findings, they indicate that both language lateralization and hand preference constitute independent polygenic complex genetic traits, despite the moderate phenotypical correlation. This implies that a large number of genes/alleles each with modest effect size (in addition to possible nongenetic factors) contribute to the phenotypic variation. Such a model is in line with previous data: results from another linkage study that tested an autosomal recessive model also argued against monogenic inheritance (Van Agtmael et al., 2003) and led the authors to suggest that left-handedness is a complex genetic trait. The pedigrees in that study did not allow to test the reducedpenetrance model that was applied in our linkage analysis because of a lack of power. Although a polygenic genetic model of handedness might appear to be at odds with the epidemiological findings that led to major gene models, such as that of McManus (1985), it has been shown that predictions of the phenotypical distribution based on a polygenic model might be indistinguishable from those resulting from a single locus model, hereby supporting the notion of handedness being a complex genetic trait (McManus et al., 2013).

The few other available linkage studies on hand preference also failed to identify evidence for linkage and resulted only in suggestive findings at loci on chromosomes 10q26 (Van Agtmael et al., 2003), 2p12 (Francks et al., 2007), and 12q21-23 (Warren et al., 2006). We did not find linkage peaks in these regions above an LOD score of 1.5 in our sample. A recent GWAS on hand skill in dyslectic subjects showed association with a locus at 15q26 (Scerri et al., 2011), whereas large-scale case-control GWASs on lefthandedness did not reveal any significant hits (Eriksson et al., 2010; Armour et al., 2014).

Regarding language lateralization, one study used discrepancies between vocabulary and spatial ability test scores from the Wechsler Intelligence Scale for Children, Third Edition, to calculate an indirect measure of cerebral asymmetry in 270 sibling pairs with attention deficit hyperactivity disorder and found linkage on chromosomes 9q33-34 and 16p13 (Smalley et al., 2005). Of these, the finding on chromosome 9q33 overlaps with our linkage findings. Previously, no genome-wide studies of biological measures of functional language lateralization have been performed. Contrary to the hypothesis of a shared genetic background for hand preference and language lateralization, none of the suggestive linkage peaks for the two traits overlapped. This absence of overlap indicated mostly separate genetic loci for handedness and lateralization, as has been suggested previously by Ocklenburg et al. (2014). Findings from our study on the relation between hand preference and language lateralization in this sample also suggested separate genetic underpinnings for these two traits (M. Somers, L. Olde Loohuis, M. F. Aukes, B. Pasaniuc, C. L. de Visser, R. S. Kahn, I. E. Sommer, and R. A. Ophoff, unpublished observations).

All of the suggestive linkage results in this study showed up previously in studies of language function or disorders associated with decreased lateralization, such as schizophrenia. The suggestive linkage peak in 22q13 was the only result for left-handedness and has not been reported previously for this trait. Deletion of the 22q13 region results in Phelan-McDermid syndrome (Phelan et al., 2001), which is characterized by hypotonia, global developmental delay, severe expressive language and speech delay, and autistic behavior (Uchino and Waga, 2013). The syndrome has been coupled to haploinsufficiency of the SHANK3 (SH3 and multiple ankyrin repeat domains 3 ) gene. In the brain, SHANK3 is expressed mainly in neurons and acts as a synaptic scaffolding protein (Uchino and Waga, 2013). Alterations in SHANK3 have also been implied in autism spectrum disorders (Manning et al., 2004; Waga et al., 2011) and schizophrenia (Gauthier et al., 2010), two disorders that have also been associated with an increased prevalence of left-handedness (Sommer et al., 2001a).

This is the first study to perform linkage analysis of atypical (i.e., right-hemispheric and bilateral) lateralization and degree of language lateralization, a quantitative measure expressing the extent to which language functions are restricted to one hemisphere. Several peaks suggestive for linkage were observed, which might indicate the involvement of multiple genes in determining these traits. Our results show suggestive linkage for atypical lateralization in the $7 \mathrm{q} 34$ region that has been shown previously to harbor genes associated with language function (Sehested et al., 2010; Schneider et al., 2012). Our results also show three suggestive linkage findings in the analysis of degree of language lateralization, on $7 q 32,9 q 33$, and $6 \mathrm{p} 22$. Region $7 q 32$ has been linked previously to dyslexia and speech sound disorder (Kaminen et al., 2003; Bates et al., 2007; Peter et al., 2012). The region on 9q33 has been linked previously to cerebral asymmetry (Smalley et al., 2005). Markers in the linkage peak in that study (e.g., D91S776) show overlap with the 1-LOD drop region of the peak in our study. A meta-analysis showed the $9 q 33$ region to be associated with schizophrenia and bipolar disorder (Wang et al., 2010), two disorders that have also been associated with decreased lateralization (Sommer et al., 2001b, 2007; Li et al., 2007). Our replication of previous findings from independent samples on related phenotypes further strengthens the support for genes in this region to play a role in language lateralization. Finally, the $6 \mathrm{p} 22$ region harbors the major histocompatibility complex genes and is of interest for its numerous associations with various traits and diseases, again including schizophrenia (Stefansson et al., 2009).

This study has a number of limitations. Although this is the first study to confirm that atypical language lateralization is heritable, the finding of a heritability of 0.31 for language lateralization might be an overestimation as a result of ascertainment bias in favor of atypical dominant subjects in our sample. Although our study provides a strong argument against the presence of a major locus for left-handedness or language lateralization in this population, it still remains possible (albeit unlikely) that such a locus exists in other populations, because our Dutch population may not be representative for all populations. Furthermore, we cannot rule out that families showing familial left-handedness might harbor major handedness genes in different chromosomal regions. However, a gene of very large effect in one the larger pedigrees in our sample might then also have shown up in our linkage analysis. This study was designed to include large pedigrees from a single population isolate to maximize power for detecting linkage. Although as many members as possible were included per family, a number of pedigrees were incomplete because some subjects refused to participate. As such, the distribution of left and right hand preference and language lateralization in our pedigrees may be affected, and informative meiosis may have been missed. This, as well as the relatively small sample size, might have affected power. Our sample was shown to have $99 \%$ power to identify a locus that explains $46 \%$ of variance. As such, it is very unlikely that a major gene for left-handedness that explains $>46 \%$ variance is present in these pedigrees. The amount of variance explained by genetic factors in the original McManus model has been suggested to decrease with an increasing proportion of left-handed subjects in a population (McManus, 1985). Because this amount is $22 \%$ in a general population sample with 
$10 \%$ left-handed subjects, the amount of explained variance in our sample with $24 \%$ left-handed subjects might be well below that. As a result, power to detect a major gene in our sample may be below $80 \%$. In contrast, the sample under investigation constitutes a genetic population isolate. Because genetic population isolates can be leveraged to increase power of genetic studies, including linkage analysis (Peltonen et al., 2000; Axenovich et al., 2009), actual power in our sample may be higher than predicted. This precludes a definite conclusion on the adequacy of power in our sample to detect a major gene.

Our results yielded a number of suggestive linkage peaks that may contain true genetic signal but may also represent falsepositive findings. Still, these near-significant findings may highlight regions with strongly increased odds to harbor genes involved in developing lateralized function. This is also supported by the overlap of a locus in our sample with another locus observed in a genetic study on brain asymmetry.

In conclusion, our results suggest that left-handedness, atypical language lateralization, and degree of language lateralization are independent but heritable polygenic traits. We did not obtain evidence for a major locus contribution to left-handedness or language lateralization in pedigrees from a population isolate in The Netherlands. Suggestive evidence of linkage was observed for a number of loci, of which one linked to the degree of language lateralization and chromosome $9 q 33$ coincides with a previous finding of cerebral asymmetry.

\section{References}

Abecasis GR, Cherny SS, Cookson WO, Cardon LR (2002) Merlin—rapid analysis of dense genetic maps using sparse gene flow trees. Nat Genet 30:97-101. CrossRef Medline

Anneken K, Konrad C, Dräger B, Breitenstein C, Kennerknecht I, Ringelstein EB, Knecht S (2004) Familial aggregation of strong hemispheric language lateralization. Neurology 63:2433-2435. CrossRef Medline

Annett M (1998) Handedness and cerebral dominance: the right shift theory. J Neuropsychiatry Clin Neurosci 10:459-469. CrossRef Medline

Annett M (1999) The theory of an agnosic right shift gene in schizophrenia and autism. Schizophr Res 39:177-182. CrossRef Medline

Annett M, Turner A (1974) Laterality and the growth of intellectual abilities. Br J Educ Psychol 44:37-46. CrossRef Medline

Armour JAL, Davison A, McManus IC (2014) Genome-wide association study of handedness excludes simple genetic models. Heredity (Edinb) 112:221-225. CrossRef Medline

Arning L, Ocklenburg S, Schulz S, Ness V, Gerding WM, Hengstler JG, Falkenstein M, Epplen JT, Güntürkün O, Beste C (2013) PCSK6 VNTR polymorphism is associated with degree of handedness but not direction of handedness. PLoS One 8:e67251. CrossRef Medline

Axenovich TI, Zorkoltseva IV, Belonogova NM, Struchalin MV, Kirichenko AV, Kayser M, Oostra BA, van Duijn CM, Aulchenko YS (2009) Linkage analysis of adult height in a large pedigree from a Dutch genetically isolated population. Hum Genet 126:457-471. CrossRef Medline

Bates TC, Luciano M, Castles A, Coltheart M, Wright MJ, Martin NG (2007) Replication of reported linkages for dyslexia and spelling and suggestive evidence for novel regions on chromosomes 4 and 17. Eur J Hum Genet 15:194-203. CrossRef Medline

Carter-Saltzman L (1980) Biological and sociocultural effects on handedness: comparison between biological and adoptive families. Science 209: 1263-1265. CrossRef Medline

Chen WM, Abecasis GR (2006) Estimating the power of variance component linkage analysis in large pedigrees. Genet Epidemiol 30:471-484. CrossRef Medline

Deppe M, Knecht S, Henningsen H, Ringelstein EB (1997) AVERAGE: a Windows $(\mathrm{R})$ program for automated analysis of event related cerebral blood flow. J Neurosci Methods 75:147-154. CrossRef Medline

Deppe M, Ringelstein EB, Knecht S (2004) The investigation of functional brain lateralization by transcranial Doppler sonography. Neuroimage 21: 1124-1146. CrossRef Medline

Eriksson N, Macpherson JM, Tung JY, Hon LS, Naughton B, Saxonov S, Avey
L, Wojcicki A, Pe'er I, Mountain J (2010) Web-based, participantdriven studies yield novel genetic associations for common traits. PLoS Genet 6:e1000993. CrossRef Medline

Francks C, Maegawa S, Laurén J, Abrahams BS, Velayos-Baeza A, Medland SE, Colella S, Groszer M, McAuley EZ, Caffrey TM, Timmusk T, Pruunsild P, Koppel I, Lind PA, Matsumoto-Itaba N, Nicod J, Xiong L, Joober R, Enard W, Krinsky B, et al. (2007) LRRTM1 on chromosome 2p12 is a maternally suppressed gene that is associated paternally with handedness and schizophrenia. Mol Psychiatry 12:1129-1139, 1057. CrossRef Medline

Gauthier J, Champagne N, Lafrenière RG, Xiong L, Spiegelman D, Brustein E, Lapointe M, Peng H, Côté M, Noreau A, Hamdan FF, Addington AM, Rapoport JL, Delisi LE, Krebs MO, Joober R, Fathalli F, Mouaffak F, Haghighi AP, Néri C, et al. (2010) De novo mutations in the gene encoding the synaptic scaffolding protein SHANK3 in patients ascertained for schizophrenia. Proc Natl Acad Sci U S A 107:7863-7868. CrossRef Medline

Kaminen N, Hannula-Jouppi K, Kestilä M, Lahermo P, Muller K, Kaaranen M, Myllyluoma B, Voutilainen A, Lyytinen H, Nopola-Hemmi J, Kere J (2003) A genome scan for developmental dyslexia confirms linkage to chromosome $2 \mathrm{p} 11$ and suggests a new locus on 7q32. J Med Genet 40: 340-345. CrossRef Medline

Knecht S, Henningsen H, Deppe M, Huber T, Ebner A, Ringelstein EB (1996) Successive activation of both cerebral hemispheres during cued word generation. Neuroreport 7:820-824. CrossRef Medline

Knecht S, Deppe M, Ringelstein EB, Wirtz M, Lohmann H, Dräger B, Huber T, Henningsen H (1998) Reproducibility of functional transcranial Doppler sonography in determining hemispheric language lateralization. Stroke 29:1155-1159. CrossRef Medline

Knecht S, Dräger B, Deppe M, Bobe L, Lohmann H, Flöel A, Ringelstein EB, Henningsen $H$ (2000) Handedness and hemispheric language dominance in healthy humans. Brain 123:2512-2518. CrossRef Medline

Lander E, Kruglyak L (1995) Genetic dissection of complex traits: guidelines for interpreting and reporting linkage results. Nat Genet 11:241-247. CrossRef Medline

Li X, Branch CA, Ardekani BA, Bertisch H, Hicks C, DeLisi LE (2007) fMRI study of language activation in schizophrenia, schizoaffective disorder and in individuals genetically at high risk. Schizophr Res 96:14-24. CrossRef Medline

Manning MA, Cassidy SB, Clericuzio C, Cherry AM, Schwartz S, Hudgins L, Enns GM, Hoyme HE (2004) Terminal 22q deletion syndrome: a newly recognized cause of speech and language disability in the autism spectrum. Pediatrics 114:451-457. CrossRef Medline

McManus IC (1985) Handedness, language dominance and aphasia: a genetic model. Psychol Med Monogr Suppl 8:1-40. Medline

McManus IC (2009) Language lateralization and psychosis (Sommer IE, Kahn RS, eds). Cambridge, UK: Cambridge UP.

McManus IC, Davison A, Armour JAL (2013) Multilocus genetic models of handedness closely resemble single-locus models in explaining family data and are compatible with genome-wide association studies. Ann N Y Acad Sci 1288:48-58. CrossRef Medline

Medland SE, Duffy DL, Wright MJ, Geffen GM, Hay DA, Levy F, VanBeijsterveldt CEM, Willemsen G, Townsend GC, White V, Hewitt AW, Mackey DA, Bailey JM, Slutske WS, Nyholt DR, Treloar SA, Martin NG, Boomsma DI (2009) Genetic influences on handedness: data from 25,732 Australian and Dutch twin families. Neuropsychologia 47:330337. CrossRef Medline

Ocklenburg S, Arning L, Hahn C, Gerding WM, Epplen JT, Güntürkün O, Beste C (2011) Variation in the NMDA receptor 2B subunit gene GRIN2B is associated with differential language lateralization. Behav Brain Res 225:284-289. CrossRef Medline

Ocklenburg S, Arning L, Gerding WM, Epplen JT, Güntürkün O, Beste C (2013) Cholecystokinin A receptor (CCKAR) gene variation is associated with language lateralization. PLoS One 8:e53643. CrossRef Medline

Ocklenburg S, Beste C, Arning L, Peterburs J, Güntürkün O (2014) The ontogenesis of language lateralization and its relation to handedness. Neurosci Biobehav Rev 43:191-198. CrossRef Medline

Oldfield RC (1971) The assessment and analysis of handedness: the Edinburgh inventory. Neuropsychologia 9:97-113. CrossRef Medline

Peltonen L, Palotie A, Lange K (2000) Use of population isolates for mapping complex traits. Nat Rev Genet 1:182-190. CrossRef Medline

Peter B, Matsushita M, Raskind WH (2012) Motor sequencing deficit as an 
endophenotype of speech sound disorder. Psychiatr Genet 22:226-234. CrossRef Medline

Phelan MC, Rogers RC, Saul RA, Stapleton GA, Sweet K, McDermid H, Shaw SR, Claytor J, Willis J, Kelly DP (2001) 22q13 deletion syndrome. Am J Med Genet 101:91-99. CrossRef Medline

Pinel P, Fauchereau F, Moreno A, Barbot A, Lathrop M, Zelenika D, Le Bihan D, Poline JB, Bourgeron T, Dehaene S (2012) Genetic variants of FOXP2 and KIAA0319/TTRAP/THEM2 locus are associated with altered brain activation in distinct language-related regions. J Neurosci 32:817-825. CrossRef Medline

Purcell S, Neale B, Todd-Brown K, Thomas L, Ferreira MAR, Bender D, Maller J, Sklar P, de Bakker PIW, Daly MJ, Sham PC (2007) PLINK: a tool set for whole-genome association and population-based linkage analyses. Am J Hum Genet 81:559-575. CrossRef Medline

Scerri TS, Brandler WM, Paracchini S, Morris AP, Ring SM, Richardson AJ, Talcott JB, Stein J, Monaco AP (2011) PCSK6 is associated with handedness in individuals with dyslexia. Hum Mol Genet 20:608-614. CrossRef Medline

Schneider E, Jensen LR, Farcas R, Kondova I, Bontrop RE, Navarro B, Fuchs E, Kuss AW, Haaf T (2012) A high density of human communicationassociated genes in chromosome 7q31-q36: differential expression in human and non-human primate cortices. Cytogenet Genome Res 136: 97-106. CrossRef Medline

Sehested LT, Møller RS, Bache I, Andersen NB, Ullmann R, Tommerup N, Tümer Z (2010) Deletion of 7q34-q36.2 in two siblings with mental retardation, language delay, primary amenorrhea, and dysmorphic features. Am J Med Genet A 152A:3115-3119. CrossRef Medline

Smalley SL, Loo SK, Yang MH, Cantor RM (2005) Toward localizing genes underlying cerebral asymmetry and mental health. Am J Med Genet Neuropsychiatr Genet 135B:79-84. CrossRef Medline

Somers M, Neggers SF, Diederen KM, Boks MP, Kahn RS, Sommer IE (2011) The Measurement of language lateralization with functional transcranial Doppler and functional MRI: a critical evaluation. Front Hum Neurosci 5:31. CrossRef Medline

Sommer IEC, Ramsey NF, Kahn RS (2001b) Language lateralization in schizophrenia, an fMRI study. Schizophr Res 52:57-67. CrossRef Medline

Sommer IEC, Vd Veer AJ, Wijkstra J, Boks MPM, Kahn RS (2007) Comparing language lateralization in psychotic mania and psychotic depression to schizophrenia; a functional MRI study. Schizophr Res 89:364-365. CrossRef Medline

Sommer I, Ramsey N, Kahn R, Aleman A, Bouma A (2001a) Handedness, language lateralisation and anatomical asymmetry in schizophrenia: meta-analysis. Br J Psychiatry 178:344-351. CrossRef Medline

Stefansson H, Ophoff RA, Steinberg S, Andreassen OA, Cichon S, Rujescu D, Werge T, Pietiläinen OP, Mors O, Mortensen PB, Sigurdsson E, Gustafsson $\mathrm{O}$, Nyegaard M, Tuulio-Henriksson A, Ingason A, Hansen T, Suvisaari J, Lonnqvist J, Paunio T, Børglum AD, et al. (2009) Common variants conferring risk of schizophrenia. Nature 460:744-747. CrossRef Medline

Uchino S, Waga C (2013) SHANK3 as an autism spectrum disorderassociated gene. Brain Dev 35:106-110. CrossRef Medline

Van Agtmael T, Forrest SM, Williamson R (2001) Genes for left-handedness: how to search for the needle in the haystack? Laterality 6:149-164. CrossRef Medline

Van Agtmael T, Forrest SM, Del-Favero J, Van Broeckhoven C, Williamson R (2003) Parametric and nonparametric genome scan analyses for human handedness. Eur J Hum Genet 11:779-783. CrossRef Medline

Waga C, Okamoto N, Ondo Y, Fukumura-Kato R, Goto Y, Kohsaka S, Uchino S (2011) Novel variants of the SHANK3 gene in Japanese autistic patients with severe delayed speech development. Psychiatr Genet 21: 208-211. CrossRef Medline

Wang KS, Liu XF, Aragam N (2010) A genome-wide meta-analysis identifies novel loci associated with schizophrenia and bipolar disorder. Schizophr Res 124:192-199. CrossRef Medline

Warren DM, Stern M, Duggirala R, Dyer TD, Almasy L (2006) Heritability and linkage analysis of hand, foot, and eye preference in Mexican Americans. Laterality 11:508-524. CrossRef Medline

Wigginton JE, Abecasis GR (2005) PEDSTATS: Descriptive statistics, graphics and quality assessment for gene mapping data. Bioinformatics 21:3445-3447. CrossRef Medline 